\title{
Understanding Corporate Tax Avoidance and the Causal Factors: Some Evidence from Malaysia
}

Muhammad Yusof Abdul Khalid, Siti Zaidah Turmin (corresponding author) and Mohd Rizal Palil

To Link this Article: http://dx.doi.org/10.6007/IJARAFMS/v11-i3/10666 DOI:10.6007/IJARAFMS /v11-i3/10666

Received: 18 June 2021, Revised: 21 July 2021, Accepted: 11 August 2021

Published Online: 26 August 2021

In-Text Citation: (Khalid et al., 2021)

To Cite this Article: Khalid, M. Y. A., Turmin, S. Z., \& Palil, M. R. (2021). Understanding Corporate Tax Avoidance and the Causal Factors: Some Evidence from Malaysia. International Journal of Academic Research in Accounting Finance and Management Sciences, 11(3), 271-283.

\section{Copyright: @ 2021 The Author(s)}

Published by Human Resource Management Academic Research Society (www.hrmars.com)

This article is published under the Creative Commons Attribution (CC BY 4.0) license. Anyone may reproduce, distribute, translate and create derivative works of this article (for both commercial and non-commercial purposes), subject to full attribution to the original publication and authors. The full terms of this license may be seen at: http://creativecommons.org/licences/by/4.0/legalcode

Vol. 11, No. 3, 2021, Pg. 271 - 283 


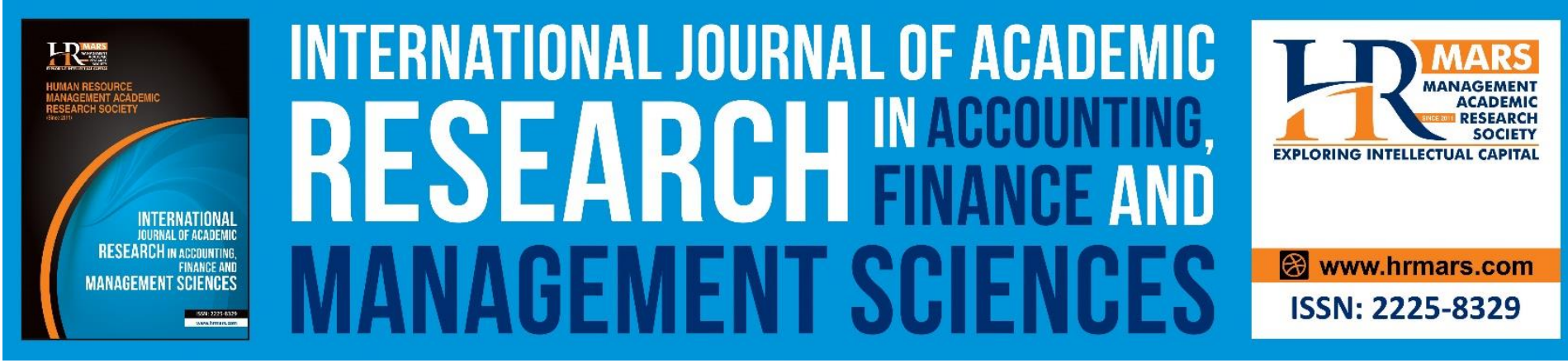

\title{
Understanding Corporate Tax Avoidance and the Causal Factors: Some Evidence from Malaysia
}

\author{
Muhammad Yusof Abdul Khalid ${ }^{1}$, Siti Zaidah \\ Turmin(corresponding author) $)^{2^{*}}$ and Mohd Rizal Palil ${ }^{3}$ \\ ${ }^{1,2}$ Department of Accounting and Finance, School of Business and Economics, Universiti \\ Putra Malaysia, ${ }^{3}$ Centre for Governance Resilience and Accountability, Faculty of Economics \\ and Management, Universiti Kebangsaan Malaysia \\ Email: muhammadyusofkhalid@yahoo.com,zaidah@upm.edu.my,mr_palil@ukm.edu.my
}

\begin{abstract}
The collection of taxes is vital in contributing towards the revenue of a country. From the perspective of Malaysia, corporate taxes are the largest contributor to the government's revenue. Despite the significant role of corporate taxes in generating revenue for the country, the Malaysian tax authority has faced tax leakages, including tax avoidance. Tax avoidance is a major challenge for Malaysia's tax system, as cases have increased from year to year. This study was conducted to identify the causal factors of tax avoidance by the corporate sector in Malaysia. The sample of the study comprised 260 Malaysian public companies listed on Bursa Malaysia from thirteen economic sectors. The data were analysed using statistical analysis of multiple regression. The study's findings revealed that three company characteristics, namely; total assets, leverage and sales growth, were significant in determining the level of tax avoidance among the companies investigated. This study was fruitful as it has contributed to the knowledge base and tax policymakers in Malaysia.
\end{abstract}

Keywords: Tax avoidance, Corporate, Malaysia, Company Characteristics, Causal.

\section{Introduction}

Taxation is the main source of revenue for most governments. Besides the importance of tax revenue in financing the development of a country (Edame \& Okoi, 2014), taxation has multiple other functions for nations as it can positively impact investment and social and economic development (Osho and Efuntade, 2020). Countries with developing economies require significant tax revenues to ensure their states' smooth and effective running at national and sub-national levels (Neog and Gaur, 2020). Taxation has a vital effect on the steady-state level of GDP per capita (Ciftci, Gokmenoglu and Yetkiner, 2018). Taxation can be used as a tool of fiscal policy to control inflation and the economic recession of a country (Kneller, Bleaney and Gemmell, 1999).

Due to the prominence of taxation for a government's revenue, all taxpayers must by law comply with tax rules and regulations. Under tax compliance, taxpayers are required to declare all of their income (Alm, 1991). However, tax authorities face the problem of tax noncompliance that disrupts the tax administration and collection process. One of the categories of tax non-compliance is tax avoidance (Mohamad \& Ali, 2016). Past studies have provided 
MANAGEMENT SCIENCES

Vol. 11, No. 3, 2021, E-ISSN: 2225-8329 @ 2021 HRMARS

several definitions of tax avoidance. Tax avoidance was defined by Mardiasmo (2016) as an effort to reduce the tax burden, which does not violate the law. Pohan (2015) stated that tax evasion was an effort to circumvent paying tax lawfully and safely, as it does not interfere with taxation provisions. The tactics and strategies used to reduce the amount of tax owed appear to take advantage of the limitations found in the laws and regulations of taxation. Taxpayers generally aim to minimise their tax payments, regardless of the lawfulness of such activity (Hanlon and Heitzman, 2010). This activity is indicated by the various means taxpayersuse to save tax and secure their income from higher tax liabilities that would otherwise have been incurred (Kiabel and Nwokah, 2009).

Looking at the perspective of Malaysia, the Royal Malaysian Customs Department recorded RM 1.3 million in taxation revenue leakages for the year 2019. That amount increased proportionately to RM 812 million for the six months from January to June 2020. According to the Director-General, Enforcement and Compliance Division of the Royal Malaysian Customs Department, tax leakages were detected from; commercial fraud, undervaluation, tax evasion, and excessive input tax claims. Malaysia recorded 617 tax avoidance cases in 2013. That number increased to 689 cases in 2014, 1063 cases in 2015, 1454 cases in 2016 and 2169 cases in 2017 (Annual Report of IRBM, 2013-2017).

According to the Royal Malaysia Customs Department Director-General, Datuk Seri T. Subromaniam, Malaysia lost RM1 billion in 2017 due to uncollected taxes. Such an amount is significant for the federal government's revenue and, thus, should be taken seriously. The figures also revealed the gap between the expected and the actual tax collection made by the government.

The significant of corporate tax in contributing to the Malaysian economic and infrastructure development is undeniable. Unfortunately, tax evasion contributes to the substantial leakage in tax collection, diminish the effectiveness of tax administration and disturb government's financial capability to implement the development programmes as planned. Corporate tax avoidance is attributed to several company's characteristics. Identifying the causal factors of tax avoidance is vital to elucidate and reduce tax leakage. Thus, this motivates the researcher to conduct the study with the aim to investigate the factors that influenced tax avoidance by listed company in Malaysia.

\section{Literature Review}

The review of existing literature on this topic has been broken down into six different factors, namely: return on assets, firm size, leverage, sales growth, capital intensity, and inventory intensity and are discussed below individually:

\section{Return on Assets}

The return on assets is the ratio between net income and total assets of a company. Nguyen, Nguyen, Le, Le and Truong (2020) examined the factors affecting corporate tax noncompliance in 187 enterprises in Ho Chi Minh City, Vietnam. Their study sample was selected based on the theoretical sampling method. The data were analysed using a probit regression model. The findings of the study showed a positive relationship between the return on assets and tax avoidance. This result was due to the sampled companies that generated greater returns by using their assets facing increased pressure to fulfil their tax obligations. However, as the calculation of their tax obligations became more time-consuming and costly, many 
MANAGEMENT SCIENCES

Vol. 11, No. 3, 2021, E-ISSN: 2225-8329 @ 2021 HRMARS

enterprises sought methods to avoid paying tax. In Indonesia, Tandean and Nainggolan (2016) investigated the factors that determined tax avoidance. Their study was conducted on 120 manufacturing companies listed on the Indonesia Stock Exchange, selected using judgment sampling. Multiple regression results revealed consistent findings with Nguyen et al (2020) regarding the relationship between the return on assets and tax avoidance. Companies with higher income conducted tax avoidance to minimise their tax payments to the authorities.

On the contrary, an inconsistent result was found by Ryandono, Ernayani, Atmojo, Susilowati and Indriastuty (2020). Their study was conducted on 19 Indonesian food and beverage companies listed on the Indonesia Stock Exchange. The companies were chosen based on purposive sampling techniques. The statistical analysis of multiple regression conducted revealed that the return on assets was not significant in influencing the companies' choices to avoid tax. This situation was due to tax avoidance being a risky activity, whereby managers were unwilling to take risks to minimise their company's investment risks. The companies would make full tax payments if their return on assets were high, while companies with a low return on assets would be less complacent regarding tax payments to maintain their assets. Therefore, there were no initiatives for tax avoidance for the sampled companies even though the sizes of the sampled companies were different.

\section{Firm Size}

Firm size is the measurement of how large or small an organisation is. Satyadini (2018) examined tax avoidance risk assessment, including the dimension and magnitude of tax risk exposure of tax avoidance. The study sample was selected using a stratified observation method from 6,005 tax-related financial statements. Other data were obtained from OECD releases, statistics and other publications. The data were analysed using statistical analysis of multiple regression. The findings showed that firm size negatively and significantly influenced tax avoidance by the companies. This outcome was deemed to be because larger companies wished to sustain themselves in the long term; thus, they tended to comply with tax regulations. Larger companies also mitigated and constructed tax compliance strategies to reduce their risks, including lowering their tax burdens. Therefore, the larger the company, the lesser the tax avoidance activities. This finding was supported by the study of Chytis, Tasios, Georgopoulos and Hortis (2019), which was carried out in Greece. Chytis et al (2019) explored the relationship between tax avoidance and corporate governance characteristics on a sample of 280 companies listed on the Athens Stock Exchange. Based on the linear regression analysis conducted, the study revealed that firm size negatively influenced tax avoidance for the investigated companies.

On the contrary, Irianto, Sudibyo and Wafirli (2017) 's research concluded different findings. Their study was conducted on 36 manufacturing companies listed on the Indonesian Stock Exchange, selected based on the purposive sampling method. The results of multiple regression analysis revealed that firm size had a positive and significant relationship with tax avoidance by the sampled companies. This outcome was probably due to higher turnover companies having opportunities to select and manipulate accounting procedures to reduce tax liabilities paid to the authorities. In addition, a study conducted by Yahaya and Yusuf (2020) on 20 insurance companies in Nigeria also revealed consistent results with Irianto et al. (2017). The generalized method of moments regression technique indicated a positive relationship between firm size and aggressive tax avoidance among the sampled companies. 
However, Kusbandiyah and Norwani (2018), through their study of aggressive tax avoidance behaviour on manufacturing companies listed in Indonesia, derived different results. A total sample of 44 companies was selected based on the purposive sampling method. The study found no significant relationship between the size of the firm investigated and their tax avoidance behaviour. Thus, the finding revealed the possibility of companies to conduct tax avoidance, regardless of their size.

\section{Leverage}

Leverage is defined as the use of debt to finance the investment of companies. Hariyanti, Rohaya, Normah and Rozainun (2013) examined the governance of accounting and tax rules on the level of tax burdens paid by SMEs in Malaysia. Their study sample consisted of 148 Malaysian small and medium enterprises (SMEs) selected by filtering, checking, and recording data processes. The data were analysed using cross-sectional regression analysis. Their findings showed that leverage had a negative relationship with effective tax rates. SMEs in Malaysia could gain benefits from interest expenses that they paid for their debt. The interest expenses reduced the amount of taxable income. The effective tax rate became lower, thus resulting in a lower amount of tax that needed to be paid by the companies than the actual tax payment. This situation led to the tax avoidance initiatives by the sampled companies. Therefore, leverage is said to have a positive relationship with tax avoidance activities.

The study by Kasim and Saad (2019) revealed consistent findings with Hariyanti et al. (2013). Kassim and Saad (2019) investigated the determinants of tax avoidance among 830 multinational corporations in Malaysia. The sampled companies were categorised as high risk regarding transfer pricing issues with effective tax rates (ETR) between $100 \%$ and $-100 \%$. The study results showed a positive and significant relationship between the sampled companies' leverage and tax avoidance activities. Once leverage increased, companies could use the interest tax shield of debt financing as a tax deduction. Companies could utilise interest and other financial payments to obtain a tax deduction. Thus, the companies' effective tax rate and chargeable income would decrease, leading to increased tax avoidance activities.

On the contrary, a diverse finding was indicated by Pratama (2017). The study was conducted on 70 Indonesian listed companies to investigate the affiliation between company characteristics, corporate governance and tax avoidance. The sampled companies were chosen based on the purposive sampling method. The results of the study revealed that leverage did not have a significant relationship with tax avoidance. This outcome may have been due to the perception of the sampled companies management that debts held by the companies were considered burdens. Thus, companies were inclined to remove the burden by paying taxes instead of employing tax avoidance activities to minimise their tax payments to the authorities.

\section{Sales Growth}

Sales growth is the percentage of increase in sales over a specific period. Oktaviyani and Munandar (2017) 's study was conducted on Indonesian listed companies in the real estate and property sector. The sample of companies was selected using the purposive sampling method. Based on the moderated regression analysis conducted, the study's findings did not reveal any significant relationship between sales growth and tax avoidance. Employees in 
MANAGEMENT SCIENCES

Vol. 11, No. 3, 2021, E-ISSN: 2225-8329 @ 2021 HRMARS

companies with greater sales growth are usually rewarded with bonuses, thus increasing their motivation to boost future sales to receive additional bonuses and rewards. Companies with higher sales growth will pay tax without the need to conduct tax avoidance. Therefore, they will not have tax avoidance initiatives related to the sales growth of the company.

However, Desmiranti and Sulhendri (2019) 's study on 27 listed Indonesian companies revealed inconsistent results. The findings of the regression analysis showed that sales growth influenced tax avoidance in a significantly positive way. This relationship might have been due to companies with higher sales growth generating higher revenues. Sales growth is a performance-based indicator for companies. Once companies achieve higher sales growth, management and employees seek to obtain rewards in terms of bonuses and salaries. However, as company revenue increases, the tax burden that the company must bear will also increase due to sales growth. Therefore, to obtain higher financial rewards, companies will tend to seek to avoid paying taxes. This result was in line with findings by Silvia (2017) concerning 58 listed manufacturing companies in Indonesia and Purwanti and Sugiyarti (2017) study concerning 75 Indonesian listed companies from the industrial and manufacturing sectors.

\section{Capital Intensity}

Capital intensity refers to the amount of capital required by companies to generate sales. Putra, Syah and Sriwedari (2018) examined tax avoidance behaviour among 100 manufacturing companies listed on the Indonesia Stock Exchange. The study found that the capital intensity of the companies positively influenced their tax avoidance behaviour, as companies with a higher level of capital intensity needed to utilise more of their assets to generate sales. This situation leads to an increase in deductible expenses, such as depreciation.

Furthermore, companies can offset deductible expenses against their income, which will result in a decrease in taxable income. Therefore, companies will pay less tax. In other words, capital intensity is known as a tax avoidance strategy. This finding was aligned with the study outcome of Kalbuana, Solihin, Saptono, Yohana and Yanti (2020) concerning 30 companies listed on the Jakarta Islamic Index and the study by Sugeng, Prasetyo and Zaman (2020) on 37 listed Indonesian manufacturing companies.

On the other hand, Hanny and Niandari (2018), through investigating 39 banking companies in Indonesia and Maula, Saifullah, Nurudin and Zakiy (2019) through studying 48 listed property and real estate companies in Indonesia, found that there was no significant relationship between capital intensity and tax avoidance. Based on these studies, companies' taxable income was not affected by asset depreciation, as depreciation expenses were lower than the company's taxable income. This situation contributed to the insignificance of capital intensity in influencing the tax avoidance activities of the companies being investigated.

\section{Inventory Intensity}

Inventory intensity is the proportion of inventory owned by a company compared to the company's total assets. Zikrullah and Martini (2019) examined the effect of company characteristics against tax avoidance in 11 Indonesian companies from the food and beverage industry. They found a negative relationship between inventory intensity and effective tax rates, thus leading to a positive relationship between inventory intensity and tax avoidance. 
MANAGEMENT SCIENCES

Vol. 11, No. 3, 2021, E-ISSN: 2225-8329 @ 2021 HRMARS

This outcome was perhaps because companies with high inventory intensity ratios would experience higher inventory costs, especially for inventory storage. This situation would reduce profit, thus, decreasing the tax burden of the companies. In other words, there would be a lower amount of corporate tax that needed to be paid by the companies. The finding was aligned with the study outcome by Putri and Lautania (2016) on 60 listed Indonesian manufacturing companies and the result of the study by Ahmad (2018) on 12 listed industrial companies in Indonesia.

Nevertheless, Yanti and Fatahurrazak (2018) 's investigation did not find any relationship between inventory intensity and tax avoidance when examining 49 manufacturing companies in Indonesia. This outcome was due to the companies not employing tax avoidance to circumvent paying corporate taxes as they are not focused on financing and investment in inventory and other assets.

\section{Research Methodology}

This study used secondary data as the research instruments. The annual reports of companies for the year 2019 were used to collect the data. The annual reports were obtained from the website of Bursa Malaysia. Out of the total population of 785 companies listed on the Main Market of Bursa Malaysia, 260 companies were selected as the sample for the study. The main market was chosen because it is the prime market for existing businesses that have reached expectations regarding their quality, scale, and operations. The sampled companies were selected based on stratified random sampling. The number of sampling units for each economic sector drawn from each stratum was proportional to the stratum population. The number of samples was determined based on the table of sample size determination by Krejcie and Morgan (1970). The sampled companies were drawn from 13 different economic sectors. Details of the number of companies in each economic sector are shown in Table 1.

Table 1

Population and Sample based on Economic Sectors

\begin{tabular}{|l|l|l|l|}
\hline No & Sector & Population & Sample Taken \\
\hline 1 & Healthcare & 13 & 4 \\
\hline 2 & Energy & 31 & 10 \\
\hline 3 & Technology & 42 & 14 \\
\hline 4 & Property & 100 & 33 \\
\hline 5 & Utilities & 12 & 4 \\
\hline 6 & Finances Services & 32 & 10 \\
\hline 7 & Telecommunications \& Media & 17 & 6 \\
\hline
\end{tabular}


MANAGEMENT SCIENCES

Vol. 11, No. 3, 2021, E-ISSN: 2225-8329 @ 2021 HRMARS

\begin{tabular}{|l|l|l|l|}
\hline 8 & Consumer Products \& Services & 171 & 57 \\
\hline 9 & Construction & 51 & 17 \\
\hline 10 & Real Estate Investment Trusts & 18 & 6 \\
\hline 11 & Industrial Products \& Services & 223 & 74 \\
\hline 12 & Plantation & 43 & 14 \\
\hline 13 & Transportation \& Logistics & 32 & 11 \\
\hline & Total & 785 & 260 \\
\hline
\end{tabular}

The study used six independent variables: return on assets, firm size, leverage, sales growth, capital intensity, and inventory intensity, while tax avoidance was the dependent variable. The operationalisation of the independent variables was based on specific mathematical formulae. Specifically, the return on assets variable was measured by net income over the company's total assets. The firm size variable was represented by total assets, while the leverage variable was measured by total debt over the companies' total assets. As for the sales growth variable was determined by dividing the current year's sales minus the previous year sales with the previous year's sales. The capital intensity variable was measured by the total fixed assets over the total assets. In contrast, the inventory intensity variable was measured by total inventory over the total assets of a company. The dependent variable of tax avoidance was proxied by the companies current effective tax rate (ETR) using the formulae of current tax expenses over income before tax.

The data were analysed using the SPSS statistical software package, version 26 . The statistical method of multiple regression was conducted to examine the relationship between the independent variables and tax avoidance.

\section{Findings}

The results of the multiple regression analysis revealed that two independent variables, namely, the return on assets and sales growth, were negatively and statistically significant in influencing the tax avoidance activities of the sampled companies. This outcome implied that companies with a higher return on assets and sales growth tended to have a lower level of tax avoidance. On the other hand, the independent leverage variable was positive and statistically significant in determining tax avoidance. This result meant that the higher the companies' leverage, the higher the level of tax avoidance. In addition, the independent variables of firm size, capital intensity and inventory intensity were statistically insignificant in determining anyytax avoidance activities of the sampled companies. Details of the multiple regression results can be referred to in Table 2 .

Table 2

Multiple Regression Result for the Tax Avoidance and the Influencing Drivers

\begin{tabular}{|c|c|c|c|c|c|}
\hline $\begin{array}{l}\text { Independent } \\
\text { Variable }\end{array}$ & $\begin{array}{l}\text { Non- } \\
\text { standard } \\
\text { Coefficient }\end{array}$ & Std. Error & t-Statistic & Sig. $T$ & VIF \\
\hline Constant & -0.564 & 3.576 & -0.158 & 0.875 & \\
\hline ROA & -0.309 & 0.075 & -4.122 & 0.000 & 1.415 \\
\hline Firm Size & -0.691 & 1.197 & -0.577 & 0.565 & 1.243 \\
\hline Leverage & -0.045 & 0.072 & 3.297 & 0.001 & 1.401 \\
\hline Sales Growth & -0.172 & 0.054 & -3.177 & 0.002 & 1.069 \\
\hline $\begin{array}{l}\text { Capital } \\
\text { Intensity }\end{array}$ & -0.066 & 0.159 & -0.418 & 0.677 & 1.206 \\
\hline
\end{tabular}




\begin{tabular}{lllll}
\hline $\begin{array}{l}\text { Inventory } \quad-0.084 \\
\text { Intensity }\end{array}$ & 0.046 & 1.830 & 0.07 & 1.045 \\
\hline Dependent variable: Tax Avoidance & & & \\
\hline Explanation of the model: & & & \\
$\mathrm{R}^{2}=0.268$ & & & \\
Adjusted $\mathrm{R}^{2}=0.228$ & & \\
\hline Durbin Watson test $=2.069$ & &
\end{tabular}

The findings of the study might be attributed to several possible reasons. First, the return on assets is a comparative performance measurement between companies in similar industries (Maeenuddina et al., 2020). The return on assets reflects the efficiency of a company in converting assets into revenue. It reflects not only the reputation of the company but also the initiatives concerning tax avoidance made by the company. In addition, the return on assets provides information to investors on the effectiveness of a company in converting the funds invested by the investors into net income. The agency theory states that there are different interests between the investors and the management of companies. One way to balance these two parties is by using performance-based compensation (Stroh et al., 1996). The better the performance of a company, the better will be the compensation received by its employees. To achieve this, companies will probably tend to improve their performance in many ways. One such method is tax avoidance, whereby companies will utilise tax reliefs and incentives provided by the government to lessen their tax burden. This action will contribute to a significant effect on tax avoidance initiatives. These perhaps contribute to the negative relationship between the return on assets and tax avoidance by companies.

Second, leverage is a valuable instrument that may help the management of companies to decide the optimal finance and investment decisions (Upcounsel.com, 2021). It is a fundamental approach in investment since it allows corporations to establish a limit in developing their company activities. Once leverage is high, companies tend to avoid tax by utilising the interest tax shield of debt financing as a tax deduction. This action will decrease the chargeable income and tax payable, thus contributing to companies' positive relationships between leverage and tax avoidance.

Third, sales growth is used by investors, analysts and corporate management to understand the performance of companies, regular business growth, and forecasting the future success of the companies. Increasing sales growth will result in boosting the profit of companies. This situation will be reflected in a company's good reputation and credibility. Companies will tend to decrease tax avoidance to maintain their reputation and credibility, thus contributing to the negative relationship between sales growth and tax avoidance.

The result of the multiple regression analysis showed that the value of the adjusted $R^{2}$ was 0.228 , thus indicating that the regression model in the study could explain nearly $23 \%$ of the association between the tax avoidance activities of the sampled companies and the influencing drivers. Specific tests for the regression model included; normality, linearity, multicollinearity, homoscedasticity, and independence of error tests, implying that all these basic assumptions had been met before running the regression model. Therefore, the study specified the regression equation as follows:

$Y=-0.564(\alpha)-0.309(R O A)-0.691\left(F \_s i z e\right)+0.237($ Lev) -0.172 (S_growth) -0.066 (Cap_Intens) $+0.084($ Inv_Intens $)+\varepsilon$. 
Annotation:

$\mathrm{Y}=$ tax avoidance

$\alpha=$ constant

ROA $=$ return on assets

F_size $=$ firm size

Lev= leverage

S-growth= sales growth

Cap_Intens= capital intensity

Inv_Intens- inventory intensity

$\varepsilon=$ error

\section{Conclusion}

As one of the World's developing economies, Malaysia depends heavily on tax revenue to execute its national development projects. The significance of corporate tax in contributing towards national income is undeniable. Through the collection of corporate tax, the government can implement and develop infrastructure projects as planned. Therefore, it is crucial to ensure that the administration and collection of corporate tax run smoothly. Thus, activities that are leading to tax leakage, including tax avoidance, should be minimised.

Findings of the study contributes in three ways. First, the findings assist government and tax administrator to evaluate the effectiveness of the initiatives that have been previously implemented. In other words, both government and tax administrator can assess whether the initiatives executed have met the targeted objectives. Also, based on the findings, the Malaysian tax authorities might consider to urge integration of initiatives as an effort to srink the tax leakage loopholes. Second, findings of the study are beneficial to the Malaysian tax authority to characterize causal factors of tax avoidance among corporation in Malaysia, hence plan and execute the appropriate strategies to ensure effectiveness of corporate tax administration and minimise corporate tax leakage. Finally, the study is valuable in contributing to the discipline of knowledge in taxation and tax behaviour. Findings of the study may be used as a reference by other developing economies in understanding the issue of tax avoidance in different perspectives.

\section{References}

Ahmad, E. F. (2018). Pengaruh Profitabilitas, Capital Intensity, Dan Inventory Intensity Terhadap Effective Tax Rate.

Alm, J. (1991). A perspective on the experimental analysis of taxpayer reporting. The Accounting Review 66(3): 577-93

Chytis, E., Tasios, S., Georgopoulos, I., \& Hortis, Z. (2019). The Relationship between Tax Avoidance, Company Characteristics and Corporate Governance: Evidence from Greece. Corporate Ownership \& Control. Vol. 16. Issue. 4. Pp. 77-86.

Ciftci, D. D., Gokmenoglu, K. K., \& Yetkiner, H. (2018). The heterogeneous impact of taxation on economic development: New insights from a panel cointegration approach. Economic Systems, 42. https://doi.org/10.1016/j.ecosys.2018.01.001 
MANAGEMENT SCIENCES

Vol. 11, No. 3, 2021, E-ISSN: 2225-8329 ๔ 2021 HRMARS

Desmiranti, D., \& Sulhendri. (2019). Determinant Tax Avoidance. International Conference on Economics, Management and Accounting. Pp. 921-947.

Edame, G. E., \& Okoi, W. W. (2014). The Impact of Taxation on Investment and Economic Development in Nigeria. Academic Journal of Interdisciplinary Studies, 3, 209-209. Expenditure: A case study of Malaysia, MPRA Paper No. 69123.

Hanlon, M., \& Heitzman, S. (2010). A Review of Tax Research. SSRN Electric Journal 50(2-3): 127-128. https://doi.org/10.1016/j.jacceco.2010.09.002

Hanny, R., \& Niandari, N. (2018). Tax Avoidance Practice: Political Connection, Firm Characteristics and Audit Quality Test at Banking Industry in Indonesia. International Journal of Business Management and Economic Research. Vol. 9(3). Pp. 1296-1303.

Hariyanti, D., Rohaya, M. N., Normah, O., \& Rozainun, A. A. (2013). The Governance of Accounting Rules and Tax Rules: Analysis of SMEs' Tax Avoidance Strategies. Global Journal of Business and Social Science Review. Vol 3. Page 26-34.

Irianto, B. S., Sudibyo, Y. A., \& Wafirli, A. (2017). The Influence of Profitability, Leverage, Firm Size and Capital Intensity Towards Tax Avoidance. International Journal of Accounting and Taxation. Vol. 5. No. 2. Pp. 33-41.

Kalbuana, N., Solihin, S. Y., \& Yanti, D. R. (2020). The Influence of Capital Intensity, Firm Size and Leverage on Tax Avoidance on Companies Registered in Jakarta Islamic Index (JII) Period 2015-2019. International Journal of Economics, Business and Accounting Research. Vol. 4. Issue. 3. Pp. 272-278.

Kasim, F. M., \& Saad, N. (2019) Determinants of Corporate Tax Avoidance Strategies among Multinational Corporations in Malaysia. International Journal of Public Policy and Administration Research. Vol. 6. Pp. 74-81.

Kiabel, B. D., \& Nwokah, N. G. (2009). Curbing Tax Evasion and Avoidance in Personal Income Tax Administration: A Study of the South-South States of Nigeria. European Journal of Economic, Finance and Administrative Sciences, Vol. 15, pp. 60-61.

Kneller, R., Bleaney, M. F., \& Gemmell, N. (1999). Fiscal policy and growth: evidence from OECD countries. Journal of Public Economics, 74. https://doi.org/10.1016/S00472727(99)00022-5

Krejcie, R. V., \& Morgan, D. (1970). Determining Sample Size for Research Activities. Educational and Psychological Measurement, 30, 607-610.

Kusbandiyah, A., \& Norwani, N. M. (2018). The Influence of Size Firm and Ownership Structure Toward Aggressive Tax Avoidance of Manufacture Companies Listed in Indonesia Stock Exchange. Advances in Social Science, Education and Humanities Research. Vol. 231. Pp. 131-135.

Maeenuddina, B. R., Hussain, A., Hafeez, M., Khan, M., \& Wahi, N. (2020). Economic Value Added Momentum \& Traditional Profitability Measures (ROA, ROE \& ROCE): A Comparative Study. Vol. 83. Pp. 13762-13774

Mardiasmo. (2016). Perpajakan (Taxation). Yogyakarta Indonesia: Andi Offset.

Maula, H., Saifullah, M., Nurudin \& Zakiy, F. S. (2019). The Influence of Return on Assets, Leverage, Size and Capital Intensity on Tax Avoidance. AFEBI Accounting Review. Vol. 4. No. 1. Pp. 49-62.

Mohamad, M., \& Ali, M. A. M. (2016). Examining the Factors of Tax Noncompliance: A Case Study of Small and Medium Enterprises in the Metro Area. SHS Web of Conferences, 36. https://doi.org/10.1051/shsconf/2017360001

Neog, Y., \& Gaur, A. K. (2020). Tax structure and economic growth: a study of selected Indian states. Economic Structures 9, 38. https://doi.org/10.1186/s40008-020-00215-3. 
MANAGEMENT SCIENCES

Vol. 11, No. 3, 2021, E-ISSN: 2225-8329 ๔ 2021 HRMARS

Nguyen, L. T., Nguyen, A. H. V., Le, H. D., Le, A. H., \& Truong, T. T. V. (2020). The Factors Affecting Corporate Income Tax Non-Compliance: A Case Study in Vietnam. Journal of Asian Finance, Economics and Businesses. Vol. 7 No. 8 2020. Page 103-115.

Oktaviyani, R., \& Munandar, A. (2017). Effect of Solvency, Sales Growth and Institutional Ownership on Tax Avoidance with Profitability as Moderating Variables in Indonesian Property and Real Estate Companies. Binus Business Review. Vol. 8. No. 3. Pp. 183188.

Osho, A., \& Efuntade, A. (2020). Impact of Taxation on Investment, Social and Economic Development in Nigeria. European Journal of Business and Management, 11.

Pohan, C. A. (2015). Manajemen Perpajakan (Management of Taxation). Jakarta, Indonesia PT. Gramedia Pustaka Utama.

Pratama, A. (2017). Company Characteristics, Corporate Governance and Aggressive Tax Avoidance Practice: A Study of Indonesian Companies. Review of Integrative Business and Economics Research. Vol. 6. Issue 4.

Purwanti, S. M., \& Sugiyarti, L. (2017). Pengaruh Intensitas Aset Tetap, Pertumbuhan Penjualan dan Koneksi Politik Terhadap Tax Avoidance. Jurnal Riset Akuntansi dan Keuangan. Vol. 5. Pp. 1625-1642.

Putra, P. D., Syah, D. H., \& Sriwedari, T. (2018). Tax Avoidance: Evidence of As a Proof of Agency Theory and Tax Planning. International Journal of Research \& Review. Vol. 5. Issue 9. Pp. 52-60.

Putri, C. L., \& Lautania, M. F. (2016). Pengaruh Capital Intensity Ratio, Inventory Intensity Ratio, Ownership Structure Dan Profitability Terhadap Effective Tax Rate. Jurnal IImiah Mahasiswa Ekonomi Akuntansi. Vol. 1. No. 1. Pp. 101-119.

Ryandono, M. N. H., Ernayani, R., Atmojo, P., Susilowati, D. \& Indriastuty, N. (2020). Factors Influencing Tax Avoidance in Indonesia. Humanities \& Social Sciences Reviews. Vol. 8. No. 1. Pp. 366-372.

Satyadini, A. E. (2018). Empirical Approach of Tax Avoidance Risk Assessment. Kajian Ekonomi \& Keuangan. Vol. 2 No 1.

Silvia, Y. S. (2017). Pengaruh Manajemen Laba, Umur Perusahaan, Ukuran Perusahaan Dan Pertumbuhan Penjualan Terhadap Tax Avoidance. Jurnal Equity. Vol. 3. Issue. 4.

Stroh, L. K., Brett, J. M., Baumann, J. P., \& Reilly, A. H. (1996). Agency Theory and Variable Pay Compensation Strategies. Academy of Management Journal. Vol. 39. No. 3. Pp. 751767.

Sugeng, Prasetyo, E., \& Zaman, B. (2020). Does Capital Intensity, Inventory Intensity, Firm Size, Firm Risk and Political Connections Affect Tax Aggressiveness? Jurnal Ilmiah Bidang Akuntansi dan Manajemen. Vol. 17. Pp. 78-87.

Tandean, V. A., \& Nainggolan, P. (2016). Faktor-Faktor yang Mempengaruhi Tax Avoidance dengan Kepemilikan Institusional sebagai Variabel Pemoderasi. Jurnal Akuntansi Bisnis. Vol. 9. No. 2. Pp. 170-185.

Yahaya, K. A., \& Yusuf, K. (2020). Impact of Company Characteristics on Aggressive Tax Avoidance in Nigerian Listed Insurance Companies. Jurnal Administrasi Bisnis. Vol. 9. No. 2. Pp. 101-111.

Yanti, D., \& Fatahurrazak. (2018). Pengaruh Profitabilitas, Capital Intensity, Inventory Intensity, Leverage Dan Risk Management Committee Terhadap Tax Avoidance Pada Perusahaan Manufaktur Yang Terdaftar Di Bursa Efek Indonesia Tahun 2013-2016. 
INTERNATIONAL JOURNAL OF ACADEMIC RESEARCH IN ACCOUNTING, FINANCE AND MANAGEMENT SCIENCES

Vol. 11, No. 3, 2021, E-ISSN: 2225-8329 @ 2021 HRMARS

Zikrullah, M., \& Martini. (2019). Characteristics of The Company and Tax Avoidance Manufacturing Company in the Food and Beverage Industry Sector Listed in Indonesia Stock Exchange Period 2012-2016. 